\title{
A Study on Educational Assortative Marriage
}

\author{
Moonju Seong \\ Dept. of Social Welfare, Namseoul Univerisity \\ 교육수준별 결혼유형에 대한 고찰 \\ 성문주 \\ 남서울대학교 사회복지학과
}

\begin{abstract}
This paper examines the relationship between education and marriage in South Korea, based on a 2 percent data of the 2000 census. The result found strong educational homogamy and wife-hypergamy over the five age cohort, 21-30, 31-40, 41-50, 51-60, and 61-70. For the primary, junior secondary, upper secondary and tertiary educational levels, the chance of marrying within the same educational level was stronger for primary and tertiary education. In terms of trends, the educational homogamy increased across the four cohorts. We note that while upward marriage was stronger for women (hypergamy), it decreased over time.
\end{abstract}

Key Words : Educational assortative marriage, Homogamy, Wife-hypergamy

요 약 본 연구는 2000 년 국민주택총조사 자료(2\% 샘플)를 사용하여 기혼 응답자 중 본인과 배우자의 학력 결합유 형에 대해 살펴보았다. 21-70세 응답자를 10년 단위로 5개 연령대별 결혼유형을 분석한 결과는 전체 결혼에서 동일 한 학력을 가진 배우자와 결혼하는 동질혼이 $65 \%$, 자신보다 고학력인 남성과 결혼하는 여성 상승혼이 $30 \%$ 로 이 두 유형이 전체 결혼유형의 $90 \%$ 를 설명하는 것으로 나타났다. 교육동질혼 경향은 모든 연령대에서 강하게 나타났으며, 교육 수준을 초등학교, 중학교, 고등학교, 대학 이상(전문대 포함)으로 구분하여 동질혼을 비교했을 때, 초등학교와 대학 이상 그룹에서 동질혼의 비율이 매우 높았다. 이러한 동질혼 경향은 젊은 세대로 갈수록 증가하였다. 그러나 여성의 상승혼은 젊은 연령대로 갈수록 감소함을 알 수 있었다.

주제어 : 교육동질혼, 상승혼, 하강혼, 교육, 결혼

\section{Introduction}

Recent studies examining educational assortative marriage have observed a common pattern of educational similarities in most industrialized countries, i.e. individuals tend to marry those with a similar level of education[1][2][3]. It is because education directly and indirectly implies occupation, income, family background and culture.

Like other countries, education is one of the most

\footnotetext{
* 본 논문은 박사학위 논문의 일부를 수정 보완한 것입니다. This paper is derived from a part of Ph.D. Thesis(2008).

본 연구는 2013년 남서울대학교 학술 연구비지원에 의해 수행되었음.

Received 25 October 2013, Revised 3 December 2013

Accepted 20 March 2014

Corresponding Author: Moonju Seong(Namseoul University)

Email: mjseong@gmail.com

ISSN：1738-1916
} 
important criteria in partner selections in South Korea (hereafter Korea). A number of studies on Korea document the existence of a strong educational homogamy[4][5]. Based on previous literatures, this paper aims to describe general marriage patterns related with educational levels for the late-half of $20^{\text {th }}$ century.

For purposes of clarification, this paper employs the following definitions: assortative marriage indicates that people tend to have non-random marriage with individuals who are similar to themselves. Assortative marriage is classified into homogamy and hypergamy. Homogamy in marriage refers to the pattern of marrying an individual with the same attributes as oneself (e.g., educational homogamy or ethnic homogamy), and hypergamy in marriage refers to upward marriage in the given aspect, such as educational qualifications and socioeconomic status. For example, wife-hypergamy in educational marriage indicates that women marry partners with higher education than themselves.

\section{Previous studies and background}

\subsection{Previous studies}

In the context of Korean research, several empirical studies have documented the significant impact of education on Korea's marriage market[6]. The country's marriage pattern in the second half of the 20th century is characterized by a strong educational homogamy and a pattern of women's marrying up[5][7]. Chang observed a similar pattern of educational assortative marriage by using 2,392 couples aged 25 to 64 taken from the 1990 and 1995

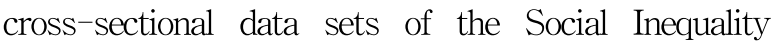
Survey conducted by the Social Science Association in Korea[7]. Park and Smits confirmed the presence of strong educational homogamy and wife-hypergamy during the 1930s-1990s[5].

Regarding trends observed, Park noted increasing educational homogamy[8], whereas Chang showed no constant trends[7]. In relation to the wife-hypergamy, an increase in the wife-hypergamy effect for the 1960s-1980s marriage cohort was observed[9] whereas no systematic trend for the 1950s-1990s marriage cohort was reported[7]. The different time spans may account for the inconsistent results. However, Park and Smits[5] found an increasing trend of educational homogamy, particularly among tertiary education for the 1930s-1990s. Hence, although it is certain that educational homogamy and hypergamy are predominant marriage patterns in Korea, it has not been established whether educational homogamy and hypergamy have persisted or increased/decreased over time.

\subsection{Background}

This section presents structural details, such as the mean age and educational attainment among Korea's marriageable population. To begin, Figure 1 reports the mean ages of first marriage. In general, the mean age for both genders increased slowly from 1960 to 2005, and the mean age for men was consistently higher. In 1960 the average marriage age is 25 years for men and 22 years for women, but in 1980, the same figures increased slightly, i.e. by 2 years for men and 3 years for women. In 2005 the data indicate even later ages, i.e. 31 years for men and 28 years for women.

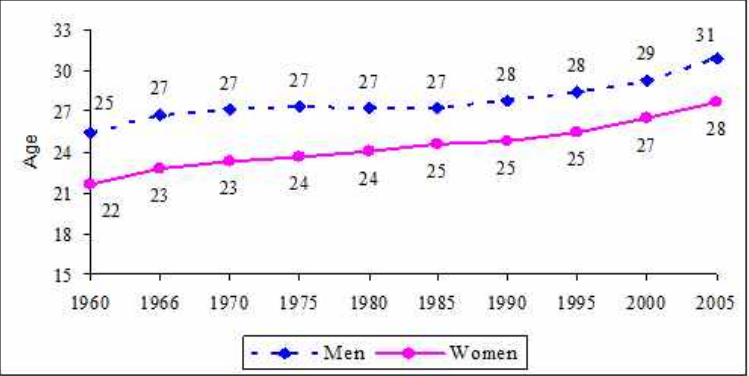

[Fig. 1] Mean Ages of First Marriage, 1960-2005 Source: [10][11][12]

Next Figure 2 presents the trends of educational 
attainment of men and women in the common marriageable age, 20 to 29 .

Among those aged 20-29, the obtained schooling years are 4.0 and 1.7 years for men and women respectively in 1945, but the gap decreased constantly, reaching parity in 1995 (12.7 years for both genders). Impressively, the 2000 figure shows that women received slightly higher education ( 0.2 years) than men.

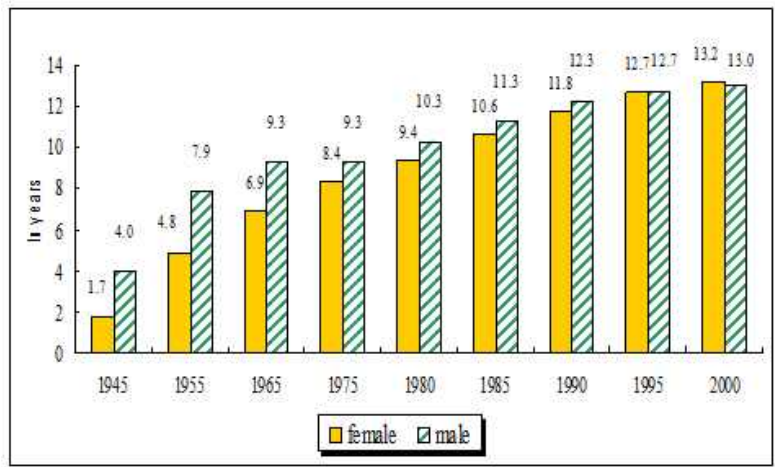

[Fig. 2] Mean Schooling Years of Population Ages 20-29 Years, 1945-2000 Source: [11][12]

If a first marriage rate is low or a divorce rate is high, the results of analyzing educational assortative marriage may be constrained. Hence, it is useful to examine family trends, i.e. marriage and divorce rates.

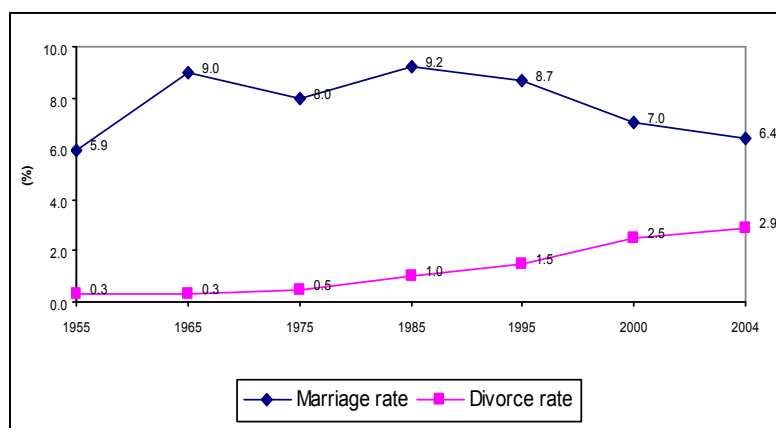

[Fig. 3] Crude Rates of Marriage and Divorce, 1955-2004

Source: [13][14]

In Figure 3, the marriage/divorce rates from 1955-2004 are conventionally calculated as the annual number of marriages/divorces per 1,000 persons. The marriage rate of 5.9 in 1955 rose to 9.0 by 1965 . From 1965 to 1995, the marriage rate remained constant at more or less 9 percent, only to decline gradually to 6.4 in 2004. In contrast, the divorce rate gradually rose from 0.3 to 0.5 between 1955 and 1975, and then increased to 2.9 in 2004. The marriage and divorce rates imply relatively stable marriage formation for the six decades.

In summary, Korean men were more highly educated until women finally caught up in 1990s. In terms of educational levels among marriageable ages, until 2005 the number of tertiary educated men was still larger than for tertiary educated women. We note that a relatively large percentage of tertiary educated men would have married down due to the shortage of female graduates, and that this situation may affect the marriage choice for both sexes with less than tertiary education. Based on these aggregate figures, we assume that with a strong educational homogamy, wife-hypergamy is also one of the predominant marriage patterns prior to the $1990 \mathrm{~s}$, but there is no solid empirical evidence, this cannot be assumed. The following sections discuss the applicability of this assumption.

\section{Data and Methods}

We use a 2 percent sample of the population and housing census surveyed in 2000. The census was conducted on every household in the country and includes information of all persons living in the household. For this study, we selected married respondents and wife's age is between 21 and 70 . Thus, we finally used 197,057 couples. As this paper focuses on absolute marriage patterns, we use cross-tabulations for the frequencies of educational levels and homogamy and hypergamy marriage patterns. 


\section{Results}

Table 1 shows the total number of couples at each educational level including the proportion of educational levels between men and women and the pattern of educational matching.

<Table 1> Educational Qualification Marriage Matching, 1960s-1990s (unit: couples)

\begin{tabular}{|c|c|c|c|c|c|}
\hline $\begin{array}{r}\text { Wife } \\
\text { Husband }\end{array}$ & Tertiary & $\begin{array}{c}\text { Upper } \\
\text { sec. }\end{array}$ & $\begin{array}{c}\text { Junior } \\
\text { sec. }\end{array}$ & Primary & $\mathrm{N}$ \\
\hline Tertiary & 31,432 & 26,024 & 1,567 & 631 & $\begin{array}{c}59,654 \\
(30 \%)\end{array}$ \\
\hline $\begin{array}{c}\text { Upper } \\
\text { secondary }\end{array}$ & 3,801 & 56,588 & 15,485 & 5,805 & $\begin{array}{c}81,679 \\
(41 \%)\end{array}$ \\
\hline $\begin{array}{c}\text { Junior } \\
\text { secondary }\end{array}$ & 113 & 3,340 & 13,009 & 9,381 & $\begin{array}{c}25,843 \\
(13 \%)\end{array}$ \\
\hline Primary & 50 & 1,048 & 2,521 & 26,262 & $\begin{array}{c}29,881 \\
(15 \%)\end{array}$ \\
\hline $\begin{array}{c}\mathrm{N} \\
(\%)\end{array}$ & $\begin{array}{c}35,396 \\
(18 \%)\end{array}$ & $\begin{array}{c}87,000 \\
(44 \%)\end{array}$ & $\begin{array}{c}32,582 \\
(17 \%)\end{array}$ & $\begin{array}{c}42,079 \\
(21 \%)\end{array}$ & $\begin{array}{c}197,057 \\
(100 \%)\end{array}$ \\
\hline
\end{tabular}

Source: Data taken from the 2 percent of 2000 census; [19]

$<$ Table 2> Inflow and Outflow of Educational Marriage Matching (in percentage)

\begin{tabular}{|c|c|c|c|c|c|}
\hline Wusband & Tertiary & $\begin{array}{c}\text { Upper } \\
\text { sec. }\end{array}$ & $\begin{array}{c}\text { Junior } \\
\text { sec. }\end{array}$ & Primary & $\begin{array}{c}\text { Total } \\
(\mathrm{N})\end{array}$ \\
\hline Tertiary & 53.7 & 43.6 & 2.6 & 1.1 & $\begin{array}{c}100.0 \\
(59,654)\end{array}$ \\
\hline $\begin{array}{c}\text { Upper } \\
\text { secondary }\end{array}$ & 4.7 & 69.3 & 19.0 & 7.1 & $\begin{array}{c}100.0 \\
(81,679)\end{array}$ \\
\hline $\begin{array}{c}\text { Junior } \\
\text { secondary }\end{array}$ & 0.4 & 12.9 & 50.3 & 36.3 & $\begin{array}{c}100.0 \\
(25,843)\end{array}$ \\
\hline Primary & 0.2 & 3.5 & 8.4 & 87.9 & $\begin{array}{c}100.0 \\
(29,881)\end{array}$ \\
\hline Tertiary & 88.8 & 29.9 & 4.8 & 1.5 & \\
\hline $\begin{array}{c}\text { Upper } \\
\text { secondary }\end{array}$ & 10.7 & 65.0 & 47.5 & 13.8 & \\
\hline $\begin{array}{c}\text { Junior } \\
\text { secondary }\end{array}$ & 0.3 & 3.8 & 39.9 & 22.3 & \\
\hline Primary & 0.1 & 1.2 & 7.7 & 62.4 & \\
\hline Total & 100.0 & 100.0 & 100.0 & 100.0 & \\
\hline (N) & $(35,396)$ & $(87,000)$ & $(32,582)$ & $(42,079)$ & 197,057 \\
\hline
\end{tabular}

Source: [19]

$30 \%$ of husbands have tertiary education and $41 \%$ have upper secondary education. Among wives, the proportion of obtaining tertiary education is $18 \%$ and the upper secondary is $44 \%$. The number of couples with same level of education is the largest (the main-diagonal cells) at $65 \%$, and the number of couples with one different level is $31 \%$.

Table 2 defines educational marriage in terms of the proportion of the destination from husbands' education to wives' (the first panel) and the destination from wives' education to husbands' (the second panel). For husbands, the most frequent pattern is to marry women with the same level of education, followed by marrying women whose education is one level lower. For example, $87.9 \%$ of men with primary education and $69.3 \%$ of upper secondary educated men have wives with the same level of education as themselves, and the homogamy rate is slightly lower for those with tertiary education (53.7\%) and junior secondary education (50.3\%). In terms of upward marriage, women are more likely to marry men with higher education than themselves, i.e. $47.5 \%$ of women with junior secondary education marry men with upper secondary education, and $29.9 \%$ of women with upper secondary education marry men with tertiary education. Wife-hypergamy is more likely to occur when the man is one level higher. For example, only $4.8 \%$ of women with junior secondary marry men with tertiary education and $1.5 \%$ of women with primary education marry men with tertiary education. From the male point of view, a relatively large number of tertiary educated men marry women with upper secondary education (43.6\%), and $36.3 \%$ of men with junior secondary education marry women with less education. At the same time, the level of women marrying down is relatively low. Table 3 illustrates the proportion of homogamy and wife-hypergamy and the other patterns. For all respondents, homogamy marriage predominates, followed by wife-hypergamy marriage, i.e. $65 \%$ of all educational marriage is homogamy and $30 \%$ is wife-hypergmay. In terms of the cohort change, two interesting trends were found: homogamy marriage increased over time and the level 
of wife-hypergamy decreased. The level of homogamy marriage continuously increased from $62 \%$ to $74 \%$ across the 61-70 age cohort to the 21-30 age cohort, and the degree of wife-hypergamy decreased from $42 \%$ in the $61-70$ age cohort to $18 \%$ in the $21-30$ age cohort.

$<$ Table $3>$ Proportion of the Type of Educational Marriage across Age Cohorts, 2000

\begin{tabular}{ccccccc}
\hline & \multicolumn{6}{c}{ In percentages (\%) } \\
& All & $61-70$ & $51-60$ & $41-50$ & $31-40$ & $21-30$ \\
\hline Homogamy & 65 & 62 & 55 & 60 & 69 & 74 \\
$\begin{array}{c}\text { Wife- } \\
\text { hypergamy }\end{array}$ & 30 & 37 & 42 & 35 & 24 & 18 \\
Others & 6 & 1 & 3 & 5 & 7 & 8
\end{tabular}

Source: [19]

\section{Conclusion}

This paper examined the patterns and trends of educational assortative marriage in Korea by using the 2 percent data of the 2000 census. Consistent with previous findings, we conclude that the most predominant marriage pattern is educational homogamy (65\%). At the same time, there is a relatively large number of women's upward marriage, wife-hypergamy. In terms of trends, the educational homogamy pattern tends to increase over the cohort. A strong educational homogamy indicates relatively close social mobility. However it also depends on the educational structures. If social minimum educational level is higher education, only tertiary education makes different educational marriage patterns. Thus, the increased educational homogamy over the cohort tends to imply the increasing educational attainment among the younger cohort. The wife-hypergamy tends to decrease over the cohort. It is mostly due to the fact of the increasing educational homogamy.

This paper is descriptive one by presenting simple cross-tabulations. Hence, for further studies, it is better to look at the behind mechanisms of marriages and explain implications of educational assortative marriages.

\section{ACKNOWLEDGEMENT}

Funding for this paper was provided by Namseoul University.

\section{REFERENCES}

[1] DiMaggio, P., \& Mohr, J., "Cultural Capital, Educational Attainment, and Marital Selection", American Journal of Sociology, vol. 90, no. 6, pp.1231-1261, 1985.

[2] Kalmijn, M., "Status Homogamy in the United States", American Journal of Sociology, vol.97, no.2, pp.496-523, 1991.

[3] Mare, R. D., "Five Decades of Educational Assortative Mating", American Sociological Review, vol. 56, no. 1, pp.15-32, 1991.

[4] Smits, J., Ultee, W. C., \& Lammers, J., "Educational Homogamy in 65 Countries: An Explanation of Differences in Openness Using Country-Level Explanatory Variables", American Sociological Review, vol. 63, no. 2, pp.264-285, 1998.

[5] Park, Hyunjoon, \& Smits, J., "Educational Assortative Mating in South Korea: Trends 1930-1998", Research in Social Stratification and Mobility, vol.23, 103-127, 2005.

[6] Brinton M. C., \& Lee, S., "Women's Education and the Labour Market in Japan and South Korea", in Brinton, M. C. (Ed.), Women's Working Lives in East Asia, pp.125-150, Stanford, Calif: Stanford University Press, 2001.

[7] Chang, Sangsoo, Social Mobility in South Korea. Seoul: Seoul National University Press, 2001.

[8] Park, Mea-hae, Educational Assortative Mating and Social Stratification in Korea and the USA: 
1950-79. Ph. D. Thesis, University of Wisconsin-Madison, 1990.

[9] Park, Kyoung-sook, The Pattern of Educational Mating in South Korea. M.A. Dissertation, Seoul National University, 1993.

[10] KWDI, Status of Women in Korea, Seoul: Korea Women's Development Institute, 1991.

[11] NSO, Population Survey, Daejeon: National Statistical Office, 2005.

[12] Seong, Moonju, Gender and Educational Inequality in South Korea: the Correlates and Consequences of Education, Ph. D. Thesis, unpublished, University of Oxford, 2008.

[13] Byun, Haw-soon, "Marriage", In Kim, D. S., Park, S. T. \& Eun, K S. (Eds.), The Demography of Korea, Vol.1, pp. 219-245, Daejeon: The National Statistical Office, 2002.

[14] NSO, Social Indicators, Daejeon: National Statistical Office, 2004.

성 문 주(Seong, Moonju)

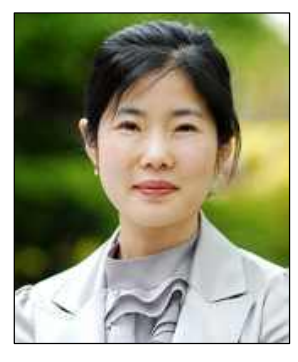

- 2000년 9월: University of York (사회정책, 석사)

·2001년 7월: University of Oxford (사회학, 석사)

·2008년 2월: University of Oxford (사회학, 박사)

- 2008년 9월-현재: 남서울대학교 사회복지학과 조교수

· 관심분야: 사회정책, 교육, 여성, 가족

·E-mail: mjseong@nsu.ac.kr 